\title{
記号に含まれるコツとパターンに含まれるコツの獲得に関する一考察†
}

\author{
井谷 久 博*·古 橋武** \\ 森 井 義 人***森，川·幸 治****
}

A Study on Acquisition of Knack Included in Symbols and Patterns ${ }^{\dagger}$

\author{
Hisahiro ITANI*, Takeshi FURUHASHI**, \\ Yoshito MORII $^{* * *}$ and Koji MORIKAWA ${ }^{* * *}$
}

\begin{abstract}
This paper discusses acquisition of knack included in symbols and patterns by a robot. Knack is defined as a rule or a sensed information that improve performance of robot drastically for a task execution. Concept of acquisition of knack included in symbols and patterns are discussed and the method to acquire the knack is presented. For acquisition of knack included in symbols, the robot acts in a new environment and success/failure data are clustered. For acquisition of knack contained in patterns, it acts in a new environment while a human modifies the output of its actuator directly, and data are clustered again. The knack in patterns is distinguished for us to interpret. Simulations using a mobile robot are done to demonstrate the acquisition of knack.
\end{abstract}

Key Words: teaching robot, acquisition of knack, autonomous mobile robot, symbols and patterns

1. はじめに

これまでに，ロボットの自律化を目的としたさまざまな研 究がなされている.しかし, 完全な自律化は困難であり，人 間の教示によるロボット作業実現の効率化が見なおされてい る $^{1)}$. 機械学習から得られる知見として, 椹木 ${ }^{2)}$ は人間か ら機械への教示行為とは, 教示者からその知識や技能が一方 的に供与されるだけではなく，教示される側からのアクティ ブな解釈活動が加わって完結する共同行為であると捉えてい る. また，認知心理学の分野では，教示が単に表面に現れる 情報だけではなく, その教示行為の背後にある意志決定·認

† SICE Annual Conference 2002 in Osaka (SICE2002) で 発表 $(2002 \cdot 8)$

* 名古屋市工業研究所 名古屋市熱田区六番 3-4-41

** 名古屋大学大学院工学研究科計算理工学専攻 名古屋市千種区不老町

*** 三重大学大学院工学研究科情報工学専攻 津市上浜町 1515

**** 松下電器産業 (株) 先端技術研究所 京都府相楽郡精華町光台 3-4

* Nagoya Municipal Industrial Research Institute, Nagoya

** Dept. of Computational Science and Engineering, Graduate School of Engineering, Nagoya University, Nagoya

*** Dept. of Information Engineering, Graduate School of Engineering, Mie University, Tsu

**** Advanced Technology Research Laboratories, Matsushita Electric Industrial Co., Ltd., Seika

(Received August 22, 2003)

(Revised March 22, 2004)
識判断のための手続きも含めた転移を伴うものでなければな らないとしている ${ }^{2)}$. 産業用ロボットの分野においては, 実 際のワークに対して現場のロボットを用いて作業を直接教示 するオンライン教示と, ロボットや環境などをコンピュータ 内でモデル化し，コンピュータ画面上で動作させることによ り教示するオフライン教示が実施されている。近年，オフラ イン教示の高度化・自動化を目指してティーチングシステム の開発が進められている ${ }^{3)}$.しかしながら, teaching play back などの教示方法だけでは手間がかかり，操作対象の物 理的特性の変動などに対処できない場合もある。適切な夕 スク表現（制御変数と状態変数）を得ることは大きな課題で

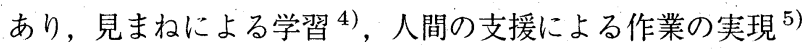
などの研究もなされている.

本稿では新しい夕スクや未知の環境下における再学習の 効率化と人間の教示の負荷の低減を目指して，人間から口 ボットへの教示方法と, ロボットによるコツの獲得方法につ いて考察する。一般にコツとは物事をなす要領もしくは勘と ころのことである.ロボットにおけるコツを定義する上で参 考となるのはスキル獲得に関する研究である。人間がルール などの記号によりロボットに教示を行なう状況で獲得される スキルを記号に含まれるスキルと呼び，人間がロボットの動 作を直接教示して獲得されるスキルをパターンに含まれる スキルと呼ぶ．記号に含まれるスキルを用いたシステムと して, 音田ら ${ }^{6)}$ はマニピュレーションスキルという基本動 作プログラムを用いて，実環境の不確定性を考慮し，作業計 画機能と作業実行機能を統合するシステムを提案している. 
このシステムでは，レンジファインダを用いて対象物の三次 元計測をし，この計測された幾何学形状の CAD データから 環境モデルの生成を行なう。そして，仮想空間内で物体モデ ルを操作しで教示を行ない，あらかじめ用意したスキルライ ブラリの中からスキルプリミティブを選択し，ロボットプロ グラムを生成するシステムを提案している。町野ら 7$)$ はマ ニピュレータの制約，七ンサの制約，ツールの制約を指標と し，教示者の判断を各指標の重みで定義し，各指標の重要度 を媒介として教示の簡便化やスキルの継承を実現する手法 を提案している。この手法を用いて，既存の教示データから 重要度を抽出し, 教示初心者への教示の補助などの教示スキ ルの再利用の可能性を示している.

また，パターンに含まれるスキルの獲得を目指した教示と して，藤本ら ${ }^{8)}$ は，モータスキル ${ }^{9)}($ 人の神経系および筋骨 格系が司る運動技能)の伝達，特にコーチが生徒に手取り足 取り教える状況に着目して, 動作の計測ならびに伝達を可能 とする機械メディアシステムを開発するとともに，コーチに よる物理的アシストを行なう力介在型のトレーニング手法 を提案している. 吉川 ${ }^{10)}$ は，機械がなんらかの作業を行な うのを人間が観察, ·体験して, 人間または動物の技能と類似 のものと感じるとき，その機械が実現している技能として人 工技能という概念を定義している.

これらの研究においてスキルは制御ルールやコツと呼べ るものを含む広い意味に用いられている，本稿におけるコッ は，この広い意味のスキルと区別するために，ある特定の夕 スク遂行に有用な制御ルールや利用情報のうち，タスク実 行の性能に大きな影響を与える最も重要なルール・利用情報 と捉える。ロボットによるコッの獲得に関連する研究として は, 大野・古橋 ${ }^{11)}$ は移動ロボットの行動獲得において, 注 視点変化をもたらす行動変化が習熟において重要であると いう仮定を設け，そのような行動ルールを抽出・利用するこ とで新たな環境下での再学習の効率化を図っている．近藤 ら ${ }^{12)}$ は, 周回行動を作業課題として与えられたロボットに おいて拘束された入力空間を，学習を効果的にするコツとし て捉えている.

筆者らはこれまでにロボットによる人間の教示情報の理 解を 2 段階に分けて考察を行なってきた ${ }^{13)}$ (14). 第 1 段階 は，教示情報の接地と捉えた ${ }^{13)}$. 記号接地問題 ${ }^{15), 16)}$ は形 式的な記号システムの意味的解釈をシステムと環境に内在 する固有のものに接地する問題である。文献 13)ではロボッ トが人間から与えられた教示情報を基にデー夕を収集し，そ のデータを基に入力情報の選択とルールの抽出を行なう機 能を持ったシステムを提案した。このシステムでは，人間か ら与えられた記号情報をロボットの物理的制約に基づいた記 号情報へと再構成した。 また, 文献 14) では教示情報の理解 の第 2 段階として, 学習された教示情報の中から未知の環 境に対してロボットが効率的な学習を可能とする入力情報を コッとして抽出することを試みた。

本稿では, 記号に含まれるコッとパターンに含まれるコ

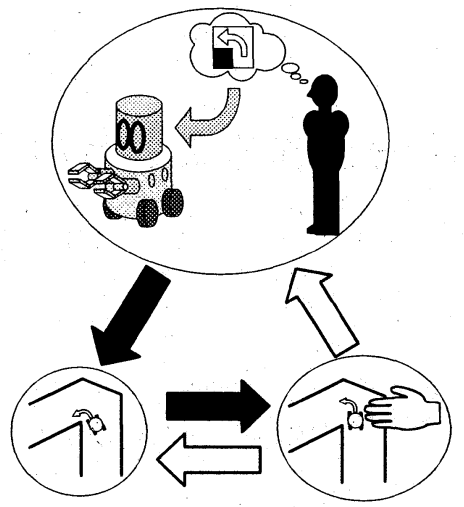

Fig. 1 Process of eaching information understanding

ツのロボットによる獲得について考察する。文献 13) と 14) で提示してきたモデルを用いて，第 1 段階の記号接地の過 程おいて，記号に含まれるコッとパターンに含まれるコッの 獲得の概念を示す.そして，これらのコッの獲得法を示す。 本手法では，記号に含まれるコツは記号的教示を基にタス ク実行の成功・失敗から得られる入出力データのクラス夕 リングにより獲得する。また，パターンに含まれるコッは， 記号的教示を通して獲得されたコツの補完として, ロボット のアクチュエータに人間が直接補正を加え，その際に得ら れたデータの再クラスタリングにより明示的に獲得される。 シミュレーションを行ない, コツ獲得の考察を行なう。

\section{2. コッの獲得と教示}

この章では，ロボットのモデルを基にロボットによるコッ 獲得について考察する。

\section{1 コッの獲得}

人間の教示情報にはルールなどで表現される記号に含ま れる情報と，ロボットのアクチュエータに直接働きかけるパ ターンに含まれる情報がある．本論文では前者を記号的な教 示情報, 後者をパターン的な教示情報と呼び，これらの情報 を教示することをそれぞれ記号的教示, パターン的教示と呼 ぶ. 記号的な教示情報が与えられた場合，ロボットはこれを ロボットの物理的制約に基づいた情報へと接地する. その過 程でロボットは教示情報に含まれるコツを獲得することが期 待される.また, パターン的な教示情報は, ロボットの入出 カデータとしてロボットに取り込まれる。この教示により口 ボット自身の持つ行動ルールに対して新しい，もしくは補足 ルールとして性能向上がもたらされるとき，それはパターン に含まれていたコツがロボットにより獲得されたと捉えら れる。ここで, 記号的教示では，人間がそのロボットと共に 体験したことのない状況に対しても，想定される状況全般 に応じて非経験的な教示ができる. 、ボットは実状況におい てその記号的教示を接地する。一方，パターン的教示では， 人間がロボットと共に経験している状況においてのみ詳細 な教示が可能である. 本稿では初めに記号的教示を行ない, パターン的教示を記号的教示の補完として行なう.

Fig. 1 に教示情報の理解の流れを示す. 図中上段のブロッ 
Robot

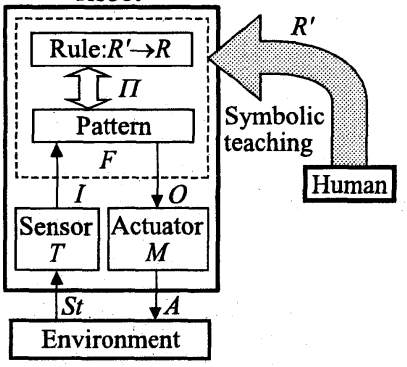

Fig. 2 Robot model

クのように人間はまず記号的な教示情報をロボットに与え る。この教示情報は図中下段左のブロックに示すようにロ ボットと環境の相互作用により接地される。ロボットは学習 した環境では適切に行動することができるが，いかなる環境 に対しても完全な記号的な教示情報をロボットに与えるこ とは不可能であるため，新しい環境では適切な行動をとれ ないこともある。したがって，その際には獲得ルールの改良 が必要となる。このルールの改良はたとえば，Fig. 1 の下段 右のブロックに示すように，記号に含まれるコッの補完とし て, ロボットの出力の補正情報をパターン的な教示情報とし て人間が与えることでなされる。この教示情報は，図中の下 段左のブロックに戻って，ロボットと環境との相互作用を通 して記号化が行なわれる。また，パターン的教示で間に合わ ない場合には，上段のブロックに戻って人間による記号的な 再教示がなされる。

\section{2 ロボットモデル}

Fig. 2 に本稿において想定するロボットのモデル 13),14)を 示す. 自律移動ロボットの存在する環境 $E$ はロボットのおか れている状態 $S t$ とロボットの行動 $A$ からなり, $E=(S t, A)$ と表わされる。ロボットのセンサ T により環境情報がロボッ トの入力 $I$ へと写像される.

$$
T: S t \rightarrow I
$$

入力デー夕は人間の脳に相当するロボットの処理系 $F$ に よって行動命令出力 $O$ に写像される.

$$
F: I \rightarrow O
$$

行動命令はアクチユエータ $M$ によって環境に対する行動 $A$ に写像される。

$$
M: O \rightarrow A
$$

記号的パターンは分類されたパターンの集合に対するラベ ルとして与えられ，ラベリングは射影 $\Pi$ で表わされる.

$$
\begin{aligned}
& \Pi: I \rightarrow S P_{I} \cup\{\perp\} \\
& \Pi: O \rightarrow S P_{O} \cup\{\perp\}
\end{aligned}
$$

射影 $\Pi$ はラベル $S P_{I}, S P_{O}$ とそれ以外 $\{\perp\}$ を与える。 こ こで, ラベル $S P_{I}, S P_{O}$ は有限の範囲の入出力パターンの 離散化であり，それぞれ入出力パターンの位相的関係を保持 している。そのため，パターンの一種と見なして記号的パ

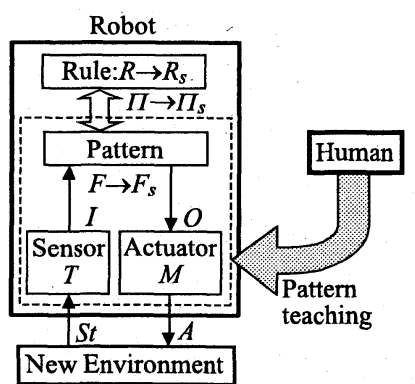

Fig. 3 Refinement of acquired rules with assist by human

ターンと呼ぶ。この記号的パターンはルール群 $R$ により以 下のように関係づけられる。

$$
R: S P_{I} \rightarrow S P_{O}
$$

記号的教示はルール群 $R^{\prime}$ をロボットに与えることでなさ れる。与えられた記号と入出力パターン間の関係づけをロ ボットが行なうことができなければ，ロボットはルール群 $R^{\prime}$ を基にして行動することはできない. 記号接地を本稿で はルール群 $R^{\prime}$ を基にして適切な $F, \Pi ， R$ を再構成する ことと位置づける. 一方, パターン的教示は, Fig. 3 に示 すように行動命令出力 $O$ に直接働きかけることでなされる. 修正された処理系 $F_{s}$ を基にして， $\Pi_{s}$ を再構成することで， 新たなルール群 $R_{s}$ を生成し，人間からのパターン的な教示 情報はルールとして明示的に獲得される。

\section{3 記号的教示}

ロボットは Fig. 1 に示す上段のブロックにおいて, Fig. 2 に示す記号に含まれるコツを含む教示情報 $R^{\prime}$ を人間から与 えられる. Fig. 1 の下段左のブロックにおいて，与えられた 教示情報に基づいて行動し，入出力デー夕を収集する。そし て, 収集されたデー夕を用いて，入力変数選択とルールの生 成が行なわれ，人間から与えられた情報をロボットの物理的 制約に基づいた情報へと再構成する，その結果，接地された $F, \Pi, R$ を獲得する。

\subsection{1 ルールの接地}

本稿では人間は教示情報をファジィルールとして与え，口 ボットはそのファジィルールを基に環境内で行動し，ファ ジィルールの再構築を行なう。文献 13) と同様に遺伝的ア ルゴリズム (Genetic Algorithm: GA) とファジィニューラ ルネットワーク (Fuzzy Neural Network: FNN) によるファ ジィモデリング手法を用いる。FNN はファジィルール群を 記述できる構造を持ったニューラルネットワークである．前 件部メン゙バシップ関数と後件部メンバシップ関数が $\Pi^{\prime}$, ファ ジィルールが $R^{\prime}$ ，ファジィ推論が $F^{\prime}$ に相当する．GAに よるファジィモデリングでは, 入力変数選択，入力空間分 割が行なわれ，FNNによりファジィルールの微調整がなさ れる。本稿では，ルール群のことをモデルと呼び，ファジィ モデリング手法により獲得されたモデルを FNN モデルと呼 ぶ. 以下に獲得の手順を示す.

STEP 1 教示情報を基に環境内で行動し，入出力デー多を 記録する。 
STEP 2 GAにより入力変数選択を行なう.

STEP 3 メンバシップ関数を逐次生成・削除することにより

入力空間の分割を行ない, FNN モデルを生成する.

STEP 4 FNN モデルの後件部の学習を行なう.

STEP 5 FNN モデルを評価し, 収束条件を満たしていれば 終了，そうでなければ STEP 2 に戻る.

\section{3 .2 モデルの改良}

接地された入力情報には，教示者によって与えられた教示 情報が完全ではないため，必要ではない情報も含まれてい る、また，ロボットは新しい環境で行動することは難しいで あろう.したがって, Fig.1の下段左のブロックから下段右 のブロックへ移行するような際には，接地された入力情報か ら必要・不必要なルールの抽出・削除を行なう必要がある. 文献 13)の FNN モデルでは入力空間が細分化されすぎてし まう傾向があり，ルールの抽出・削除には必ずしもむいてい ない．そこで，本稿ではクラスタリングにより FNN モデル として得られたルールを簡略・明示化し，ルールの抽出・削 除を行なう。ひとつのクラス夕はひとつのルールを表わす。

本稿では，クラスタリングにより獲得されたモデルを FCM モデルと呼ぶ。. 以下の手順により，モデルを改良する。

STEP 1 接地された FNN モデルを基に環境内で行動し，入 出力データを記録する.

STEP 2 記録されたデータをクラスタリングする.

STEP 3 タスク失敗時と成功時の全入出力データの各クラ スタに対する所属度をそれぞれ計算する。

STEP 4 STEP 3 の所属度について頻度解析を行なう.

STEP 5 クラス夕 $i$ に対して, “成功時のデー夕の所属度 $>\alpha_{1}$ ”となるデータの相対頻度を $f_{s i}$, “失敗時の デー夕の所属度 $>\alpha_{1}$ ”となるデー夕の相対頻度を $f_{f i}$, 基準值を $\alpha_{2}$ とするとき，次式を満たすクラ ス夕を削除する。

$$
\left\{\begin{array}{l}
f_{f i}>2 f_{s i} \\
f_{f i}>\alpha_{2}
\end{array}\right.
$$

本稿ではデータのクラスタリングにファジィc 平均法 (Fuzzy c-Means: FCM) ${ }^{17)}$ を用いる。 それぞれのクラス夕 の中心ベクトルにより, 入出力関係すなわちルールが示さ れる.

クラスタリングはデータ間の近さの度合いに応じて, データ をいくつかのクラスタにグループ化する手法である。いま，ク リスタリングされる $n$ 個の $p$ 次元データを $\boldsymbol{x}_{k}(k=1, \ldots, n)$ とし, クラス夕数を $c$, クラス夕 $i(i=1, \ldots, c)$ の中心べク トルを $\boldsymbol{v}_{i}, u_{i k}\left(0 \leq u_{i k} \leq 1\right)$ を $\boldsymbol{x}_{k}$ のクラス夕 $i$ に対する 所属度とする。このとき，FCM は次式で表わされる目的関 数の最小化問題に対する解法である.

$$
J_{m}=\sum_{i=1}^{c} \sum_{k=1}^{n}\left(u_{i k}\right)^{m}\left\|\boldsymbol{x}_{k}-\boldsymbol{v}_{i}\right\|^{2}
$$

ただし， $m$ は $m>1$ のファジィ性の度合いを決めるパラ メー夕,

$$
\sum_{i=1}^{c} u_{i k}=1
$$

である。

以下に FCM のアルゴリズムを示す.

STEP 1 中心ベクトル $\boldsymbol{v}_{i}$ と所属度 $u_{i k}$ の初期值を適当に 決める。

STEP 2 次式により新しい $\boldsymbol{v}_{i}$ を計算する.

$$
\boldsymbol{v}_{i}=\frac{\sum_{k=1}^{n}\left(u_{i k}\right)^{m} \boldsymbol{x}_{k}}{\sum_{k=1}^{n}\left(u_{i k}\right)^{m}}
$$

STEP 3 次式により新しい $u_{i k}$ を計算する.

$$
u_{i k}=1 / \sum_{j=1}^{c}\left(\frac{\left\|\boldsymbol{x}_{k}-\boldsymbol{v}_{i}\right\|^{2}}{\left\|\boldsymbol{x}_{k}-\boldsymbol{v}_{j}\right\|^{2}}\right)^{1 /(m-1)}
$$

STEP 4 収束条件を満たしていれば終了，そうでなければ STEP 2 に戻る.

\section{4 パターン的教示}

クラスタリングにより得られた FCM モデルを新しい環境 に適用するとき，もし，ロボットが問題なく行動することが できれば，新しい環境に対するルールはすでに得られていた ことになる。しかし， ロボットが獲得したルールでは, 新し い環境で適切に行動することは難しい場合もある。したがっ て, Fig.1の下段右のブロックのように，ロボットが不十分 な行動をしているときに，人間がアクチュエータの出力に直 接補正を加えることでパターン的教示を行なう。この教示に よりロボットが適切な行動をとることができるようになれ ば，パターン的教示は適切であったと捉え，パターンには口 ボットのコッが含まれていると考える．本稿では，以下の手 順により，成功時の入出力データをクラスタリングすること でパターンに含まれるコツをルールとして明示化する。

STEP 1 FCM モデルにより新しい環境内で行動する.

STEP 2 不十分な行動時に人間による補正を加え，入出力 データを記録する。

STEP 3 記録されたデー夕を基に，もとの FCM モデルの クラスタ数を増加させたクラス夕数でクラスタリ ングを行ない，新たなクラスタを得る。ただし，も との FCM モデルのクラスタの中心ベクトルは変 化させない。

上で得られた FCM モデルから出力を計算するためには， 所属度（適合度）と $p-1$ 次元のデータが必要である。し かし，獲得されたモデルに基づいて環境内で行動するとき， デー夕は $p-1$ 次元の入力データしか得られないので, 出 力を計算することはできない. 本稿では, 簡略化ファジィ推 論法 ${ }^{18)}$ を変形して出力を得る. (11) 式を以下のように変形 する。

$$
u_{i}^{\prime}=1 / \sum_{j=1}^{c}\left(\frac{\left\|\boldsymbol{x}-\boldsymbol{v}_{i}^{\prime}\right\|^{2}}{\left\|\boldsymbol{x}-\boldsymbol{v}_{j}^{\prime}\right\|^{2}}\right)^{1 /(m-1)}
$$

ただ， $\boldsymbol{v}_{i}^{\prime}$ は $\boldsymbol{v}_{i}$ から $p$ 番目の要素を削除したものである. 次式より出力值を計算する。 


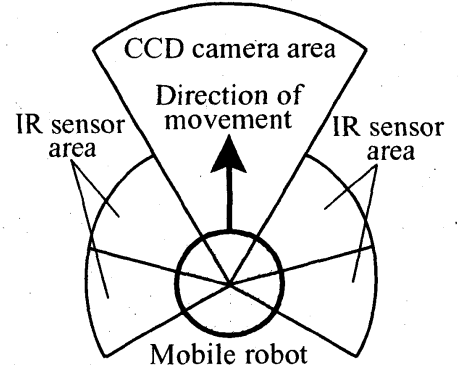

Fig. 4 Sensing area

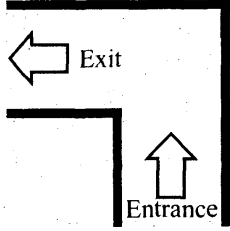

(a) Aisle 1 (A1)

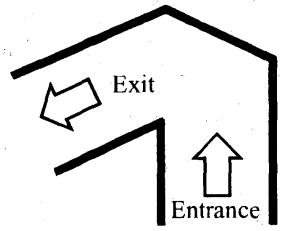

(b) Aisle 3 (A3)
Fig. 5 Aisles

$$
\hat{y}=\frac{\sum_{i=1}^{c} v_{i} \cdot u_{i}^{\prime}}{\sum_{i=1}^{c} u_{i}^{\prime}}
$$

$$
\text { 3. シミュレーション }
$$

簡単な例題として, 移動ロボットが壁に衝突することなく 等間隔の通路を通り抜ける通路通過問題を考える.

\section{1 シミュレーション設定}

自律移動ロボットは直径 $20 \mathrm{~cm}$ の円形とし, 壁面検出用の センサとして, CCD カメラと IR センサを装備し, 0.1secご とにセンシングを行なうものとする．Fig. 4 は本ロボット のセンシング領域を示す. CCD カメラは自律移動ロボット の中心に搭載され, 進行方向正面から左右 30 度, $400 \mathrm{~cm}$ 先 までの物体を撮ることができ，本稿では壁面までの距離の検 出に用いる．IR センサは自律移動ロボットの進行方向（時計 回りを正とする)，加 50.5 度 (右前)，110 度 (右)，-50.5 度 (左前), -110 度 (左) の方向に固定され, 一定距離 $(50 \mathrm{~cm})$ 以内の壁面の有無を検出できる. Fig. 5(a) に通路を示す. 通路は入口から出口まで一定幅 $250 \mathrm{~cm}$ で, 左に直角に曲がっ ている。自律移動ロボットは 1 ステップに最大左右 20 度の 方向転換が可能で, 壁面との衝突回避行動は方向転換のみ で行ない，一定速度 $(10 \mathrm{~cm} / \mathrm{sec})$ で進行する. Table 1 の ファジィルールをロボットに教示した．Fig. 6 に人間が与 えるファジィルールの前件部メンバシップ関数と後件部メン バシップ関数を示す.ただし，入力としてロボットと壁面の 最短距離方向の相対角度を用い, 出力には回転角度を用いて いる。このルールは，基本的には，ロボットに対して最短距

Table 1 Fuzzy control rules given by human

\begin{tabular}{|c||c|c|c|c|c|}
\hline Input & Right & $\begin{array}{c}\text { Middle } \\
\text { right }\end{array}$ & Center & $\begin{array}{c}\text { Middle } \\
\text { left }\end{array}$ & Left \\
\hline \hline \multirow{2}{*}{ Output } & $\begin{array}{c}\text { Middle } \\
\text { left } \\
\text { turn }\end{array}$ & $\begin{array}{c}\text { Left } \\
\text { turn }\end{array}$ & $\begin{array}{c}\text { Left } \\
\text { turn }\end{array}$ & $\begin{array}{c}\text { Right } \\
\text { turn }\end{array}$ & $\begin{array}{c}\text { Middle } \\
\text { right } \\
\text { turn }\end{array}$ \\
\hline
\end{tabular}

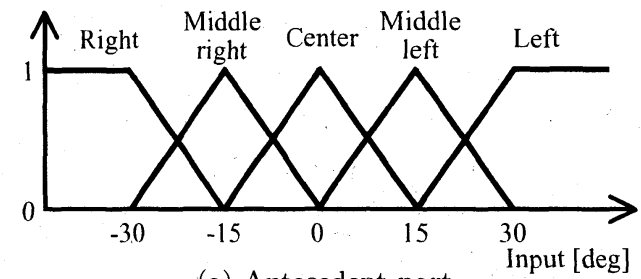

(a) Antecedent part

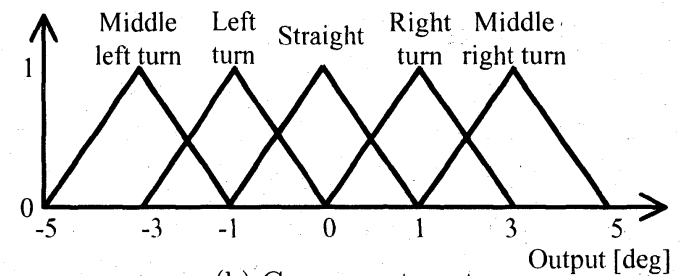

(b) Consequent part

Output [deg]

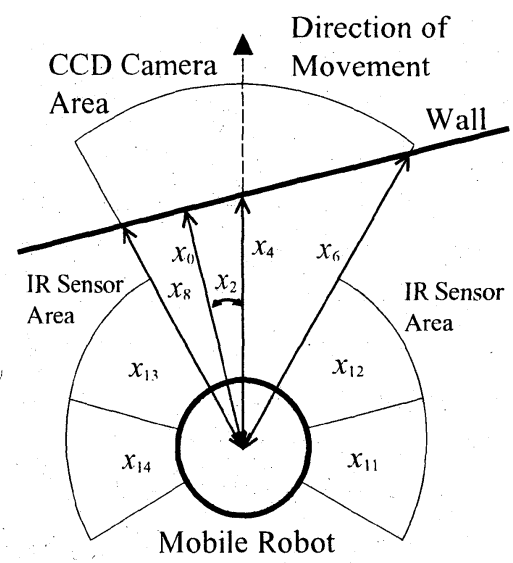

Fig. 7 Input information
Fig. 6 Membership functions

離にある壁が左右にあるときはこれを避け，壁が正面に来た ときに左に旋回するように考えられたものである。このと き人間から与えられたファジィルール群は $R^{\prime}$ に対応するも のであり，記号は $S P_{I}^{\prime}, S P_{O}^{\prime}$ に対応する。自律移動ロボッ 卜はこの教示情報に基づいて通路通過行動を行なう。壁面 に衝突することなく出口に到達するまでに 15 種類の入力情 報 $\left(x_{0}\right.$ : 壁面との最短距離, $x_{1}$ : 最短距離の変化, $x_{2}$ : 最短 距離方向の相対角度, $x_{3}$ : 最短距離方向の相対角度の変化, $x_{4}$ : 前方距離, $x_{5}$ : 前方距離の変化, $x_{6}$ : 視野の右端距離, $x_{7}$ : 右端距離の変化, $x_{8}$ : 左端距離, $x_{9}$ : 左端距離の変化, $x_{10}: 1$ ステップ前の出力, $x_{11}$ : 右後壁面の有無, $x_{12}$ : 右前 壁面の有無, $x_{13}$ : 左前壁面の有無, $x_{14}$ : 左後壁面の有無） と 1 種類の出力情報 ( $y$ : 回転角度) を記録する. Fig. 7 に 入力情報の一部を示す. 外乱 (雑音) として平均 0 , 標準偏 差 $5 \%$ の正規分布の誤差をセンシングデータに付加する.

\section{2 シミュレーション結果}

本稿の設定では利用可能な入力変数は 15 個もあり, 人間 が教えたルールの入力変数より多い.ロボットが環境内で 行動する過程において，2.3 節のステップを通して，より適 切な入力変数の組み合わせが求められ, 人間の教示ルール はこの入力変数を基に再構築される.Fig. 5(a)の通路（通 
路 1, (A1)) においてロボットの初期位置と向きをランダム に変え，教示情報を用いて通路通過行動を 50 回行なった。 その際得られた入出力データを用いて GA と FNNを用い て入力変数選択とルールの抽出を行ない，FNN モデルを獲 得した。得られた FNN モデルを用いて，通路 1 と未学習 の Fig.5(a) の通路を左右反転させた 90 度右回り（通路 2, (A2))，Fig. 5(b)の 120 度左回り（通路 3, (A3)）の通路 通過行動を 100 回行なった。以上を 1 回の試行とし, 200 回の試行を繰り返し，200 種類の FNN モデルを獲得した，

Table 2 に成功率が通路 1 で $90 \%$ 以上，通路 2 で $90 \%$ 以上， 通路 3 で $45 \%$ 以上の FNN モデルにおける入力変数の使用 頻度を示す。この表より，入力変数のうち “ $x_{2}$ ：最短方向の 相対角度”，“ $x_{8}$ ：視野左端における壁との相対距離”のみを 使用することにする．Table 3 に得られた FNN モデルの 例を示す。

上記の入力変数 $x_{2}, x_{8}$ のみを使用する FNN モデルを対 象とし，通路 1-3 の通路通過を行ない，失敗ルールを削除し FCM モデルを獲得した。ただし，本稿では，クラス夕数を $6, m=2, \alpha_{1}=0.8, \alpha_{2}=0.01$ とした．通路 2 ではモデ ルによりコーナで回転しすぎてコーナに衝突する行動，ま たは左側の壁に衝突する行動をとった，通路 3 ではモデル によりコーナで回転しすぎてコーナに衝突する行動，また はコーナ付近で回転せず失敗する行動をとった。それぞれの 場合の入出力デー夕を失敗データとして保存した．Table 4 に FNN モデルとそのモデルにより獲得されたルール削除 前・後の FCM モデルの通路 1-3 に対する通路通過成功率を それぞれ示す。それぞれのFNN モデルとルール削除前・後 の FCM モデルは一対一に対応する。この表の FCM モデル では 1 または 2 個のクラスタが削除された。 Table 4 より，

Table 2 Frequency of use of inputs

\begin{tabular}{|c||r|r|r|}
\hline Inputs & A1 & A2 & A3 \\
\hline \hline$x_{0}$ & 2 & 2 & 1 \\
\hline$x_{1}$ & 0 & 2 & 0 \\
\hline$x_{2}$ & 35 & 45 & 24 \\
\hline$x_{3}$ & 7 & 4 & 6 \\
\hline$x_{4}$ & 3 & 3 & 0 \\
\hline$x_{5}$ & 1 & 0 & 0 \\
\hline$x_{6}$ & 0 & 1 & 0 \\
\hline$x_{7}$ & 1 & 1 & 1 \\
\hline$x_{8}$ & 18 & 40 & 11 \\
\hline$x_{9}$ & 1 & 1 & 1 \\
\hline$x_{10}$ & 0 & 0 & 0 \\
\hline$x_{11}$ & 4 & 6 & 0 \\
\hline$x_{12}$ & 0 & 4 & 0 \\
\hline$x_{13}$ & 8 & 5 & 6 \\
\hline$x_{14}$ & 12 & 21 & 8 \\
\hline
\end{tabular}

Table 3 Example of fuzzy rules of FNN model[ $\left[\times 10^{-2}\right.$ rad. $]$

\begin{tabular}{|rr||r|r|r|r|}
\hline$x_{2}\left[\times 10^{-1}\right.$ rad. $]$ & $x_{8}[\mathrm{~cm}]$ & 0 & 300 & 375 & 400 \\
\hline \hline-5.24 & 1.66 & 2.10 & 0.00 & 2.43 \\
\hline 5.24 & -2.27 & -2.59 & 0.00 & 1.02 \\
\hline
\end{tabular}

ほほ同様な通路通過成功率でルニル数の少ない FCM モデル が獲得できた。Table 5 にルール削除前の FCM モデルの 一例を示す。この例ではクラス夕 5 と 6 が後に削除された. つぎに通路 2 と 3 に対して人間が補助を行ない，2.4節 のステップによりパターンに含まれるコッの明示化を行なっ た．通路 2 ではモデルによりコーナで回転しすぎる場合，ま たは左側の壁に接触しそうな場合に対して，人間による補正 がなされた，通路 3 ではモデルによりコーナで回転しすぎ る場合，またはコーナ付近で回転しない場合に対して，人間 による補正がなされた。Table 6 に新しい FCM モデルの 成功率を示す。これらは，通路 2 または 3 に対するルール 獲得の前後で成功率が大きく改善された例である．Table 7,8 に通路 2,3 それぞれに対して人間の補正後の FCM モ デルの一例を示す. Table 7 ではクラスタ 5 , Table 8 では クラスタ 6 が新たに獲得されたルールである。この例では 左側の壁に接触しそうな場合に対して，人間による補正が なされた. Table 7 のラスタ 5 はロボットに対して最短距 離にある壁が左側で，かつ，視野の左端にある壁との距離が 近いときに，大きく右回転を行なうというルールとして読 みとることができる。すなわち，移動ロボットが通路左側の

Table 4 Success rates of FNN models and FCM models[\%]

\begin{tabular}{|c|c|c|c|c|c|c|c|c|c|}
\hline \multirow[t]{2}{*}{$\begin{array}{c}\text { Model } \\
\text { No. }\end{array}$} & \multicolumn{3}{|c|}{ FNN } & \multicolumn{3}{|c|}{$\begin{array}{c}\text { FCM } \\
\text { before } \\
\text { deletion of } \\
\text { failing } \\
\text { rule(s) }\end{array}$} & \multicolumn{3}{|c|}{$\begin{array}{c}\text { FCM } \\
\text { after } \\
\text { deletion of } \\
\text { failing } \\
\text { rule(s) }\end{array}$} \\
\hline & $\mathrm{A} 1$ & A2 & A3 & $\overline{\mathrm{A} 1}$ & $\mathrm{~A} 2$ & A3 & A1 & A2 & A3 \\
\hline 1 & 82 & 87 & 62 & 80 & 96 & 39 & 83 & 98 & 39 \\
\hline 2 & 77 & 2 & 29 & 74 & 6 & 28 & 85 & 9 & 30 \\
\hline 3 & 88 & 67 & 63 & 10 & 78 & 20 & 69 & 43 & 57 \\
\hline 4 & 84 & 2 . & 37 & 86 & 8 & 32 & 82 & 6 & 25 \\
\hline 5 & 86 & 74 & 52 & 0 & 75 & 11 & 79 & 97 & 59 \\
\hline 6 & 84 & 68 & 41 & 84 & 99 & 26 & 72 & 76 & 30 \\
\hline 7 & 90 & 48 & 38 & 71 & 83 & 24 & 86 & 97 & 43 \\
\hline
\end{tabular}

Table 5 Center vectors before deletion of failing rule

\begin{tabular}{|c||r|r|r|}
\hline Cluster & $x_{2}\left[\times 10^{-1}\right.$ rad. $]$ & $x_{8}[\mathrm{~cm}]$ & $y\left[\times 10^{-2}\right.$ rad. $]$ \\
\hline \hline 1 & -0.03 & 334 & 0.08 \\
\hline 2 & -4.97 & 282 & 2.17 \\
\hline 3 & 5.18 & 252 & -2.45 \\
\hline 4 & -5.13 & 399 & 2.43 \\
\hline 5 & 5.20 & 106 & -2.36 \\
\hline 6 & -5.13 & 95 & 1.87 \\
\hline
\end{tabular}

Table 6 Success rates before/after assistance by human[\%]

\begin{tabular}{|c||r|c|c|c|}
\hline \multicolumn{1}{|c||}{\multirow{2}{*}{$\begin{array}{c}\text { Model } \\
\text { No. }\end{array}$}} & \multicolumn{2}{|c|}{ Before } & \multicolumn{2}{c|}{ After } \\
\cline { 2 - 5 } & A2 & A3 & A2 & A3 \\
\hline \hline 1 & 98 & 39 & - & 56 \\
\hline 2 & 9 & 30 & 97 & 34 \\
\hline 3 & 43 & 57 & 97 & 70 \\
\hline 4 & 6 & 25 & 97 & 71 \\
\hline 5 & 97 & 59 & - & 72 \\
\hline 6 & 76 & 30 & 91 & 46 \\
\hline 7 & 97 & 43 & - & 60 \\
\hline
\end{tabular}


壁に接触しそうな状況に陥る手前で，右回転により壁との 衝突を回避させるものである。このルールは特にクラス夕 3 のルールによる不十分な回避行動を補足するルールになっ ており，通路 2 においてこのルールを獲得したことにより， 移動ロボットは通路の左側の壁に衝突することはなくなり, 成功率が大幅に向上している．記号的教示の補完としてパ ターン的教示による適正な補助がなされ，通路 2 に対する ロボットのコツが獲得されたと考える.

一方, Table 8 の例ではロボットがコーナ付近で回転しな い場合に対して，人間による補正がなされた。Table 8のク ラスタ 6 のルールはロボットに対して最短距離にある壁が右 側で，かつ，視野の左端にある壁との距離が遠いときに大き く左回転を行なうものである。このルールは同テーブルのク ラスタ 3 の状況に似ているが，クラスタ 3 のルールはロボッ トに対して最短距離にある壁が右側で，かつ，視野の左端に ある壁との距離が遠いときに高い所属度となり，右回転を行 なうものである.クラスタ 6 のルールがない場合, クラスタ 3 のルールにより左側コーナがロボットの左側の視野外にき たとき，ロボットは右回転することによりコーナから離れて しまっていた。しかし，クラスタ 6 のルールを獲得したこと により，ロボットは左回転によりコーナの回転ができた。

本稿において人間が教示したルールは，人間の視点に立っ て設計されたもので，ロボットに対して最短距離にある壁が 視野の左右にあるときは小さく，視野のやや左右にあるとき はこれを大きく避け，壁が正面に来たときには左に旋回する ものである。通路 2 において，最短距離にある壁が左側で, かつ，視野の左端にある壁との距離が近い状況で，小さく右 回転を行なうという人間による教示ルールに対して，大き く右回転を行なうというルールが人間の補助により獲得さ れた。また, 通路 3 において, 最短距離にある壁が右側で, かつ, 視野の左端にある壁との距離が遠い状況で, 小さく左 回転を行なうという人間による教示ルールに対して，大きく 左回転を行なうルールが獲得された、いずれのルールもそれ ぞれの通路に対して有効であった。これらの結果より，人間

Table 7 Center vectors of clusters for aisle 2

\begin{tabular}{|c||r|r|r|}
\hline Cluster & $x_{2}\left[\times 10^{-1}\right.$ rad. $]$ & $x_{8}[\mathrm{~cm}]$ & $y\left[\times 10^{-2}\right.$ rad. $]$ \\
\hline \hline 1 & -0.03 & 334 & 0.08 \\
\hline 2 & -4.97 & 282 & 2.17 \\
\hline 3 & 5.18 & 252 & -2.45 \\
\hline 4 & -5.13 & 399 & 2.43 \\
\hline 5 & 5.13 & 54 & -5.30 \\
\hline
\end{tabular}

Table 8 Center vectors of clusters for aisle 3

\begin{tabular}{|c||r|r|r|}
\hline Cluster & $x_{2}\left[\times 10^{-1}\right.$ rad. $]$ & $x_{8}[\mathrm{~cm}]$ & $y\left[\times 10^{-2}\right.$ rad. $]$ \\
\hline \hline 1 & -5.10 & 400 & 2.43 \\
\hline 2 & 4.15 & 318 & -1.50 \\
\hline 3 & -4.86 & 304 & -2.52 \\
\hline 4 & 5.14 & 98 & -2.42 \\
\hline 5 & 5.14 & 203 & -2.37 \\
\hline 6 & -4.86 & 300 & 8.87 \\
\hline
\end{tabular}

による適切な補助が与えられた場合，最初に教示を行なった 環境とは異なる環境においても成功率の高いルールを明示 的に獲得できた。

\section{4. おわりに}

本稿では，自律移動ロボットに対して人間が行なう教示と ロボットによる教示情報からのコッ獲得について考察した。 ロボットのモデルを用いて，文献 13)，14）の第 1 段階の記 号接地の過程おいて，記号に含まれるコッとパターンに含ま れるコッの獲得の概念を示した。 そして，これらのコッの獲 得法を示した。本手法では，記号に含まれるコツは新しい夕 スクの実行における成功・失敗データのクラスタリングによ り獲得した。また，パターンに含まれるコツは記号に含まれ るコッの補完として，ロボットのアクチュエータに人間が直 接補正を加え，その際に得られたデータの再クラスタリン グにより明示的に獲得された。シミュレーションを行ない, コツルールを明示的に獲得できることを示した。

文献 14)の教示情報の理解の第 2 段階は, 学習された教 示情報の中から未知の環境に対してロボットが効率的な学習 を可能とする入力情報をコッとして抽出するというもので あった．本稿のコツは学習環境における行動を適切なものと するためのポイントとなるルールが明示化されたものであ り，未知環境における再学習の際に基本行動ルールとして利 用することで，その効率化に寄与すると期待される.

\section{参 考 文 献}

1）植川 剛：ミ二特集「作業の教示とプログラミング」，日本口 ボット学会誌, 17-2, 157 (1999)

2）椹木哲夫: 知識獲得と教示, 日本ロボット学会誌，13-5, 588/591 (1995)

3）長尾, 尾上：産業用ロボットの教示作業とオープン化, 日本ロ ボット学会誌, 18-4, 486/490 (2000)

4）宮本弘之：ヒト運動の最適化原理と見まねに基づくタスク学習, 日本ロボット学会誌, 19-5, 547/550 (2001)

5）石川, 古川, 鈴木：人間の操作支援により作業を遂行する移動口 ボットシステム, 日本ロボット学会誌, 20-2, 173/179 (2002)

6）音田，小笠原，比留川，北垣，中村，築根：実環境行動計画 に基づく作業ロボットシステム, 日本ロボット学会誌, 18-7, 979/994 (2000)

7) 町野, 南條, 津田：複数の作業制約と人の判断を融合したロボッ ト教示システムの提案ーセンサエンハンストロボットによる経 路追従作業への適用一，日本ロボット学会誌，18-8, 1097/1104 (2000)

8）藤本, 佐野, 松下：アクティブメディアを用いたコーチによる スキル伝详，日本ロボット学会誌，19-2，225/232 (2001)

9) R.A. Schmidt : Motor Control and Learning (2nd edition), Human Kinetics Publishers, Inc. (1988)

10）吉川恒夫：人工技能-技能の理解とその機械化-, 計測と制御, 37-7, 465/470 (1998)

11）大野, 古橋：注視点制御知識による仮想的な移動ロボットの行 動獲得手法, 電気学会論文誌, 119-C, 2, 157/163 (1999)

12) T. Kondo, N. Ito and K. Ito : An Incremental Learning using Schema Extraction Mechanism for Autonomous Mobile Robot, Proc. 2003 IEEE International Symposium on CIRA, 1126/1131 (2003)

13）井谷, 古橋：衝突回避運動における自律移動ロボットによる教 示情報の接地に関する一考察, 計測自動制御学会論文集, 36-8, 
$692 / 697(2000)$

14）井谷, 古橋：自律移動ロボットによる教示情報の理解, 計測自 動制御学会論文集, 38-11, 966/973 (2002)

15) Stevan Harnad: The Symbol Grounding Problem, Physica $\mathrm{D}, 42,335 / 346$ (1990)

16）麻生英樹：情報統合技術一実世界知能のためのキーテクノロ ジー-, RWC NEWS, 5 (1996)

17）日本ファジイ学会編：ファジィとソフトコンピューティングハ ンドブック，共立出版 $(2000)$

18）水本雅晴：ファジィ制御の改善法（III），第 5 回ファジィシス テムシンポジウム, 499/504 (1989)

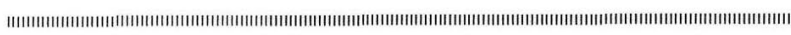

$$
\text { [著者紹介] }
$$

井谷久 博

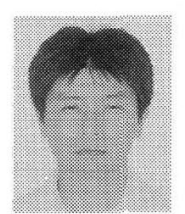

1991 年名古屋工業大学大学院博士前期課程修 了. 同年名古屋市工業研究所入所. 現在, 電子 情報部制御技術研究室に所属. ソフトコンピュー ティングの研究, 振動試験に従事. 日本ロボット 学会会員.

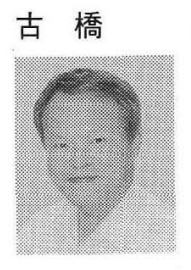

武

1985 年名古屋大学大学院工学研究科電気系専 攻博士課程後期課程修了. 同年 (株) 東芝, 88 年 名古屋大学工学部助手, 90 年同助教授, 2001 年 三重大学工学部教授, 2004 年名古屋大学大学院 工学研究科教授, 現在に至る.ソフトコンピュー テイングの研究に従事 (工学博上).

森井義人

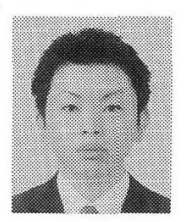

2002 年三重大学工学部情報工学科卒業, 2004 年三重大学大学院工学研究科情報工学専攻博士前 期課程修了. 同年 (株) トヨタテクノサービス入 社, 現在に至る。

\section{森川幸 治}

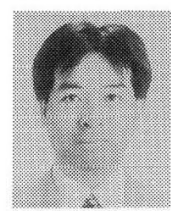

1996 年名古屋大学大学院工学研究科博士後期 課程修了. 97 年松下電器産業 (株) 入社. 現在, 先端技術研究所 知能情報技術研究所に所属. 人間 の認知機構のモデル化や機械学習に関する研究に 従事. 人工知能学会会員 (工学博士). 